\title{
RELATIONSHIP BETWEEN ANTI-VIRAL ANTIBODIES AND RHEUMATOID FACTOR IN PREGNANT WOMEN*
}

\author{
BY \\ M. WALlER, J. SEVER, N. CURRY, AND M. R. GILKESON \\ From the Department of Medicine, Medical College of Virginia, Richmond, Virginia, and the Section of \\ Infectious Diseases, NINDB, National Institutes of Health, Bethesda, Maryland, U.S.A.
}

The influence of viral infections on the incidence of rheumatoid factor in a normal population was noted by Dresner and Trombly (1959). Five per cent. of 140 normal subjects gave positive latexfixation tests for rheumatoid factor, and all seven individuals had or developed mild acute viral infections of the upper respiratory tract. In all seven subjects, tests for rheumatoid factor (RF) became negative 6 days to 6 weeks after the physical manifestations of their infection subsided. It was also noted that 83 per cent. of 35 patients with specific acute viral infections gave positive tests. In the cases followed serially, the RF activity was found to disappear in convalescence.

Johnson and Hall (1958) noted positive latexfixation tests in 65 per cent. of seventeen cases of rubella. The incidence of positive tests was higher in patients with arthritis than in those without arthritis; however, no comparison was made between the magnitude of the specific anti-viral response and the titre of RF activity.

On the other hand, Bach, Grieble, and Anderson (1965) found that, in a group of 231 aged individuals, C-F, anti-viral antibody responses showed a negative correlation with the presence of RF. Failure to show antibody to influenza A and B 3 months after immunization was significantly related to the presence of rheumatoid factor.

Rawson, Abelson, and McCarty (1961) showed that group $\mathrm{O}$ rheumatoid arthritics have consistently lower haemagglutinin titres than do normal subjects of the same blood group. This was believed to reflect a decrease in activity associated with IgG globulins.

Recently, Svec and Dingle (1965) found, in an analysis of sera from persons exposed to the 1957 influenza epidemic, that 15 per cent. of those showing a significant viral antibody response gave positive

* This investigation was supported by NIH grants AM 04549 and NIH NB 02363. This is publication 4 of the Charles W. Thomas Arthritis Fund. tests for RF as opposed to $1 \cdot 3$ per cent. of those showing no increase in viral antibody titre. The $A$ two groups studied were comparable in age and sex distribution.

Thus, there is some conflict in the literature as to $\mathrm{O}$ the significance of anti-viral responses in modifying $\overrightarrow{ }$ the expression of positive serologic tests for RF.

The purpose of this study was to compare the ability of normal individuals (pregnant women) with $\ddot{\ominus}$ RF to form complement-fixing anti-viral antibodies with their matched controls. The matching included 0 those factors known to contribute to increased virus experience.

\section{Material and Methods}

Among 1,027 pregnant women tested for RF, 26 were found to be persistently positive on two or more occasions $\frac{\text { 음 }}{3}$ during their pregnancy. These women were participants in the Child Development Study, and duplicates of sera were available for testing for C-F antibodies for viruses. Furthermore, because of the large number of participants in this study, it was possible to match these 26 women with 43 controls. For the purpose of virology, the matching included those factors which are known to contribute to increased virus experience. This included $\delta$ age ( \pm 2 years), race, number of living children, last 3 menstrual period ( \pm 2 weeks), and date of the serum 을 specimens $( \pm 2$ weeks). These controls were pregnant women who had negative tests for RF.

Rheumatoid factor was tested for by means of the slide latex test (Hyland), sensitized human cell (SHC) test, and $\mathrm{N}$ sensitized sheep cell (SSC) test by methods described previously (Waller, Decker, Toone, and Irby, 1961).

Methods for preparing complement-fixing viral anti- $\omega$ gens and for the performance of the complement-fixation tests have been described (Sever, 1962; Sever, Huebner, Castellano, and Bell, 1963). Two to four serum samples $\frac{\mathrm{C}}{\mathbb{1}}$ taken during pregnancy were tested, both for RF and C-F anti-viral antibodies, except in four instances when $\square$ only one serum sample was available. Each serum sample was matched as described with a serum sample $\overrightarrow{\mathbb{D}}$ from another pregnant woman with negative tests for $\frac{?}{\Phi}$ RF. 
The antibody tests were performed with 27 viral antigens, but only the results with 23 were tabulated because in the other instances too few individuals had detectable antibody. In the preliminary testing all serum samples were first tested at a $1: 8$ dilution in single tests. Statistical evaluation of these tests showed some significant differences. However, it was apparent that crossreactions could account for some of the differences; and, therefore, the sera were titrated with the viral antigens that on preliminary testing had shown significant differences between abnormals and controls.

In addition, the women were divided into two groups, those with positive tests for RF by two or more methods and those with only the slide latex test positive or only the SHC test positive in low titre, and the data for antibody were analysed in this way.

\section{Anti-viral Responses}

In no instance was a single C-F anti-viral antibody universally detectable in the sera of individuals with positive tests for RF and absent in the matched controls.

In the preliminary screening, it was noted that the test group with RF failed to make as many anti-viral antibodies as did the control group. $\chi^{2}$ tests of significance for each of the 23 viruses tested showed 3 that in four instances $(P<0 \cdot 10)$ the control group $\frac{\mathrm{O}}{6}$. produced significantly more complement-fixing anti- ? viral antibodies than did the group with rheumatoid $\overrightarrow{\vec{\rho}}$ factor (Fig. 1a).

When the 26 women with rheumatoid factor were $\frac{\partial}{5}$ divided into two groups (those with a high titre of $\overline{\frac{7}{5}}$ RF demonstrable usually by more than one test and $\vec{\nabla}$ those with only positive latex tests or low titres of RF with the SHC test), the high-titre group showed $\$$ that in six instances $(P<0 \cdot 10)$ the control group $\overrightarrow{0}$ produced more complement-fixing anti-viral anti- $\vec{\overrightarrow{ }}$ body (Fig. 1b). In a separate evaluation of a second $\omega_{\sigma}$ serum sample taken later in the pregnancy of women with high titre of RF and their matched controls, $\frac{\overline{0}}{2}$ $\chi^{2}$ tests showed significance $(P<0.05)$ in seven or instances (Fig. 1c).

Although there were only significant differences in six and seven instances respectively for production of specific anti-viral antibodies, it was observed that $\triangle$ the group of women with RF failed to show as high a percentage of antibody as did the matched controls. Tests of significance could not be performed in all

\section{- - Rheumatoid factor present Matched controls}

26 Women with Rheumatoid Factor and Their 43 Matched Controls

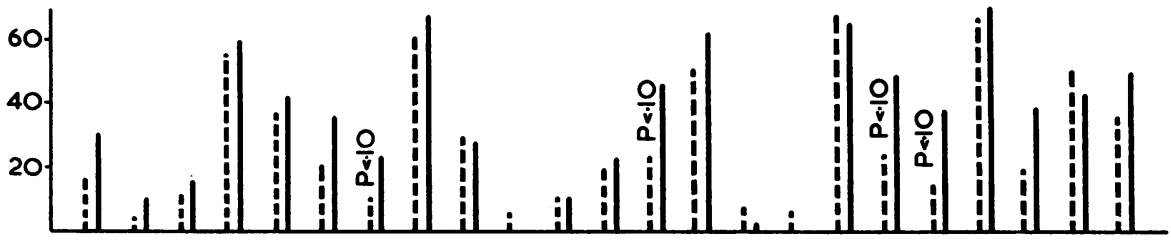

13 Women with High Titre of Rheumotoid Factor and Their 22 Matched Controls

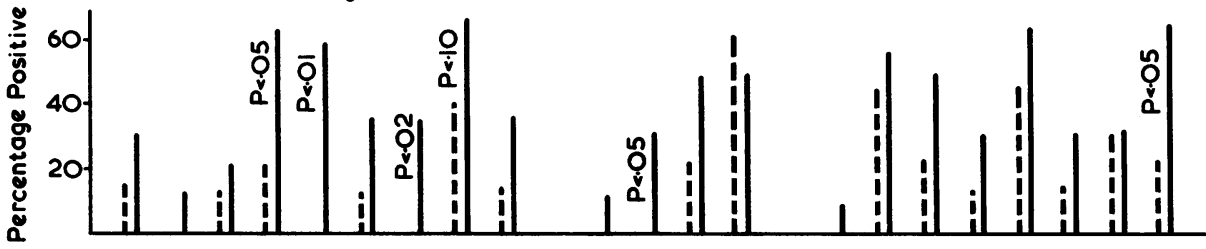

(b)

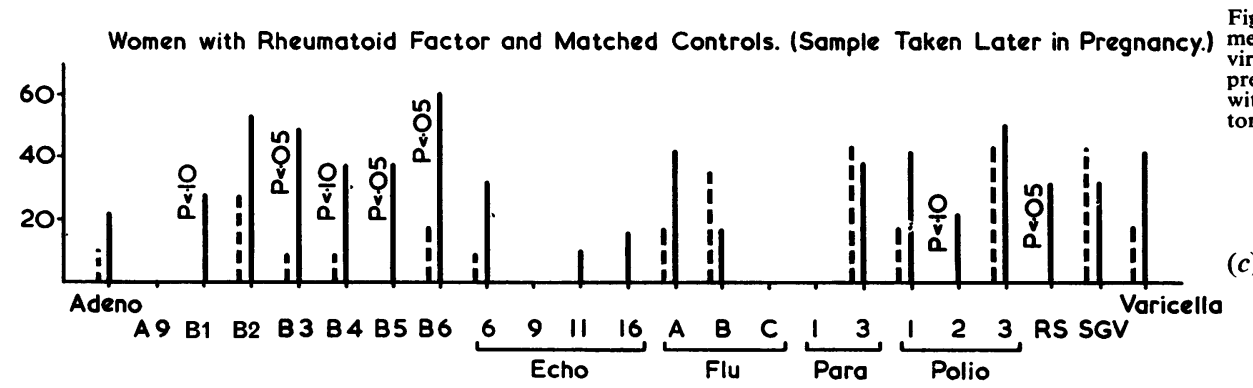

Figure. - Complement-fixing antipregnant women with rheumatoid fac- $\omega$ tor and their match- $\omega$ ed controls. 
TABLE I

PRESENCE OF ANTIBODY IN 26 WOMEN WITH RHEUMATOID FACTOR AND THEIR 43 MATCHED CONTROLS

\begin{tabular}{|c|c|c|c|c|c|c|c|c|}
\hline \multirow{3}{*}{ Virus } & \multicolumn{4}{|c|}{ Rheumatoid Factor } & \multicolumn{4}{|c|}{ Matched Controls } \\
\hline & \multicolumn{2}{|c|}{ Positive } & \multicolumn{2}{|c|}{ Fourfold Rises } & \multicolumn{2}{|c|}{ Positive } & \multicolumn{2}{|c|}{ Fourfold Rises } \\
\hline & No. & Percentage & No. & Percentage & No. & Percentage & No. & Percentage \\
\hline $\begin{array}{rr}\text { Cox- } & \mathbf{B}_{1} \\
\text { Sackie } & \mathbf{B}_{2} \\
& \mathbf{B}_{3} \\
& \mathbf{B}_{4} \\
& \mathbf{B}_{5} \\
& \mathbf{B}_{6}\end{array}$ & $\begin{array}{r}3 \\
12 \\
12 \\
8 \\
5 \\
16\end{array}$ & $\begin{array}{l}11 \cdot 5 \\
46 \cdot 2 \\
46 \cdot 2 \\
30 \cdot 8 \\
19 \cdot 2 \\
61 \cdot 5\end{array}$ & $\begin{array}{l}2 \\
0 \\
3 \\
4 \\
3 \\
2\end{array}$ & $\begin{array}{r}7 \cdot 7 \\
11 \cdot 5 \\
15 \cdot 4 \\
11 \cdot 5 \\
7 \cdot 7\end{array}$ & $\begin{array}{r}8 \\
20 \\
24 \\
20 \\
11 \\
24\end{array}$ & $\begin{array}{l}17 \cdot 4 \\
43 \cdot 5 \\
52 \cdot 2 \\
43 \cdot 5 \\
23 \cdot 9 \\
52 \cdot 2\end{array}$ & $\begin{array}{l}3 \\
1 \\
2 \\
4 \\
2 \\
1\end{array}$ & $\begin{array}{l}6 \cdot 5 \\
2 \cdot 2 \\
4 \cdot 3 \\
8 \cdot 7 \\
4 \cdot 3 \\
2 \cdot 2\end{array}$ \\
\hline Echo & 4 & $15 \cdot 4$ & 0 & & 15 & $32 \cdot 6$ & 2 & $4 \cdot 3$ \\
\hline Flu & 6 & $23 \cdot 1$ & 0 & & 21 & $45 \cdot 7$ & 1 & $2 \cdot 2$ \\
\hline $\begin{array}{ll} & 1 \\
\text { Polio } & 2 \\
& 3\end{array}$ & $\begin{array}{r}6 \\
5 \\
13\end{array}$ & $\begin{array}{l}23 \cdot 1 \\
19 \cdot 2 \\
50 \cdot 0\end{array}$ & $\begin{array}{l}1 \\
1 \\
2\end{array}$ & $\begin{array}{l}3 \cdot 8 \\
3 \cdot 8 \\
7 \cdot 7\end{array}$ & $\begin{array}{l}22 \\
14 \\
30\end{array}$ & $\begin{array}{l}47 \cdot 8 \\
30 \cdot 4 \\
65 \cdot 2\end{array}$ & $\begin{array}{l}1 \\
0 \\
1\end{array}$ & $\begin{array}{l}2 \cdot 2 \\
2 \cdot 2\end{array}$ \\
\hline $\mathrm{RS}$ & $1 * *$ & $3 \cdot 8$ & 0 & & 18 & $39 \cdot 1$ & 2 & $4 \cdot 3$ \\
\hline Varicella & 10 & $38 \cdot 5$ & 0 & & 19 & $41 \cdot 3$ & 0 & \\
\hline
\end{tabular}

instances because the numbers were small. Although the $\mathbf{P}$ values are not highly significant in this series, it is of interest that in no instance did the control group (negative for RF) produce significantly less anti-viral antibody than did the test group (positive for RF).

When all the 26 women with RF were analysed (Fig. $1 a)$, it was found that, for seventeen of the virus antigens, the percentage of women with antibody was higher in the matched controls. For six of the virus antigens, the percentage of antibody producers was higher in the 26 women with RF. The probability that this could occur by chance was less than $P<0.01$ (Dixon and Massey, 1951). When only thirteen women with a high RF titre were analysed (Fig. 1b), it was found that, for twenty of the virus antigens, the percentage of response was higher in the matched controls; in one instance a higher percentage of women with RF produced the antibody; and in two instances no antibody was produced by either group $(P<0 \cdot 001)$ (Dixon and Massey, 1951).

Nevertheless, after surveying the data, it became apparent that there was crossing among the viral antigens. To document this further, the test was titrated. Table I shows the presence of antibody in the 26 women with RF and their 43 matched controls. The only antigen which shows significantly less antibody for the women with RF is respiratory syncytial virus $(\mathrm{P}<0 \cdot 05)$. However, once again the controls never produced significantly less antibody than the women with positive tests for RF. It is noted that the titrated specimens did not always give the same percentage of positive responses (at $1: 8$ or above) as the single test survey, but reproducibility between the screen and titration if $<85$ per cent. Our data

TABLE II

PRESENCE OF ANTIBODY IN 13 WOMEN WITH HIGH TITRE OF RHEUMATOID FACTOR AND THEIR MATCHED CONTROLS AND FOUR FOLD RISES WITHIN FIRST TO LAST SPECIMENS

\begin{tabular}{|c|c|c|c|c|c|c|c|c|c|c|c|c|}
\hline \multirow{3}{*}{ Virus } & \multicolumn{4}{|c|}{ First Sample } & \multicolumn{4}{|c|}{ Last Sample } & \multicolumn{4}{|c|}{ Fourfold Rises } \\
\hline & \multicolumn{2}{|c|}{13 RF Positive } & \multicolumn{2}{|c|}{23 Controls } & \multicolumn{2}{|c|}{12 RF Positive } & \multicolumn{2}{|c|}{21 Controls } & \multicolumn{2}{|c|}{12 RF Positive } & \multicolumn{2}{|c|}{21 Controls } \\
\hline & No. & Percentage & No. & Percentage & No. & Percentage & No. & Percentage & No. & Percentage & No. & Percentage \\
\hline $\begin{array}{rr}\text { Cox- } & \mathbf{B}_{1} \\
\text { Sackie } & \mathbf{B}_{2} \\
& \mathbf{B}_{3} \\
& \mathbf{B}_{4} \\
& \mathbf{B}_{5} \\
& \mathbf{B}_{8}\end{array}$ & $\begin{array}{l}1 \\
5 \\
2 \\
3 \\
0 \\
5\end{array}$ & $\begin{array}{r}7 \cdot 7 \\
38 \cdot 5 \\
15 \cdot 4 \\
23 \cdot 1 \\
38 \cdot 5\end{array}$ & $\begin{array}{r}5 \\
9 \\
13 \\
8 \\
8 \\
13\end{array}$ & $\begin{array}{l}22 \cdot 7 \\
40 \cdot 9 \\
59 \cdot 1 \\
36 \cdot 4 \\
36 \cdot 4 \\
59 \cdot 1\end{array}$ & $\begin{array}{l}0 \\
1 \\
2 \\
2 \\
0 \\
3\end{array}$ & $\begin{array}{r}8 \cdot 3 \\
16 \cdot 7 \\
16 \cdot 7 \\
25 \cdot 0\end{array}$ & $\begin{array}{r}5 \\
8 \\
10 \\
8 \\
7 \\
12\end{array}$ & $\begin{array}{l}23 \cdot 8 \\
38 \cdot 1 \\
47 \cdot 6 \\
38 \cdot 1 \\
33 \cdot 3 \\
57 \cdot 1\end{array}$ & $\begin{array}{l}1 \\
0 \\
0 \\
1 \\
1 \\
0\end{array}$ & $\begin{array}{l}8 \cdot 5 \\
8 \cdot 5 \\
8 \cdot 5\end{array}$ & $\begin{array}{l}3 \\
1 \\
2 \\
3 \\
1 \\
1\end{array}$ & $\begin{array}{r}14 \cdot 3 \\
4 \cdot 8 \\
9 \cdot 5 \\
14 \cdot 3 \\
4 \cdot 8 \\
4 \cdot 8\end{array}$ \\
\hline Echo & 0 & & 8 & $36 \cdot 4$ & 0 & & 4 & $19 \cdot 0$ & 0 & & 1 & $4 \cdot 8$ \\
\hline Flu & 2 & $15 \cdot 4$ & 11 & $50 \cdot 0$ & 1 & $8 \cdot 3$ & 10 & $47 \cdot 6$ & 0 & & 1 & $4 \cdot 8$ \\
\hline $\begin{array}{l}1 \\
2 \\
3\end{array}$ & $\begin{array}{l}2 \\
1 \\
3\end{array}$ & $\begin{array}{r}15 \cdot 4 \\
7 \cdot 7 \\
23 \cdot 1\end{array}$ & $\begin{array}{r}10 \\
7 \\
14\end{array}$ & $\begin{array}{l}45 \cdot 5 \\
31 \cdot 8 \\
63 \cdot 6\end{array}$ & $\begin{array}{l}2 \\
0 \\
4\end{array}$ & $\begin{array}{l}16 \cdot 7 \\
33 \cdot 3\end{array}$ & $\begin{array}{r}8 \\
5 \\
12\end{array}$ & $\begin{array}{l}38 \cdot 1 \\
23 \cdot 8 \\
57 \cdot 1\end{array}$ & $\begin{array}{l}1 \\
1 \\
0\end{array}$ & $\begin{array}{l}8 \cdot 5 \\
8 \cdot 5\end{array}$ & $\begin{array}{l}1 \\
0 \\
0\end{array}$ & $4 \cdot 8$ \\
\hline$\overline{R S}$ & 1 & $7 \cdot 7$ & 6 & $27 \cdot 3$ & 0 & & 7 & $33 \cdot 3$ & 0 & & 2 & $9 \cdot 5$ \\
\hline Varicella & 3 & $23 \cdot 1$ & 11 & $50 \cdot 0$ & 3 & $25 \cdot 0$ & 7 & $33 \cdot 3$ & 0 & & 0 & \\
\hline
\end{tabular}


do not show an increased incidence of C-F anti-Flu $A$ in the women with positive tests for RF. There was no significant difference between the two groups in their ability to produce anti-viral antibodies in high titre (Table I, p. 329).

Table II shows the difference in incidence of anti-viral antibodies between the thirteen women with high-titre RF and their matched controls. The first and last samples (during pregnancy) are analysed separately.

The numbers are too small for proper statistical evaluation, but it is obvious that the women with strongly positive RF titres do not produce as many C-F anti-viral antibodies as their matched controls.

There are no significant differences between the two groups in their ability to produce high titre antiviral antibodies.

\section{Women with Positive Tests for Rheumatoid Factor}

Among the 1,027 women tested for RF, 26 had at least one test persistently positive on two or more occasions during their pregnancy. These women were divided into two equal groups as previously discussed. In the first group, all had positive tests as determined by the slide latex reagent (Hyland). In the second group, two women had all three tests positive [slide latex, SHC test (1:80 and 1:160), and SSC test (both $1: 80$ )]; nine women had both positive slide latex tests and SHC tests (1:40$1: 1280)$; and two women had only SHC tests positive (1:80 and $1: 160)$.

\section{Discussion}

Although the pregnant women with positive tests for RF showed a lower incidence of C-F anti-viral antibodies than the group of matched controls, the differences were not highly significant except for respiratory syncytial virus, one of the 23 viral antigens studied. Four times rises in antibody titre showed no significant differences between the two groups. Half of these $\mathbf{2 6}$ women had RF demonstrable only by a slide flocculation test. Separate tabulation of a selected group of the thirteen women with the highest RF titres showed more striking differences from their matched controls.

Although some investigators (Rawson, Abelson, and McCarty, 1961) have noted a lessened antibody activity in patients with rheumatoid arthritis associated with the IgG globulins, other workers have demonstrated an increase in antibody activity to certain antigens such as brucella (Meiselas, Zingale, Lee, Richman, and Siegel, 1961). In the latter instance, the hyper-reactivity was associated with the IgM globulins.

These studies agree with those of Bach, Grieble, and Anderson (1965). In both instances a nonrheumatoid population with positive tests for RF was found to show a negative correlation with the frequency of C-F anti-viral antibodies.

In no instance could we implicate any of the virus antigens studied as the agent probably eliciting RF activity in the individuals studied.

A number of investigators have noted the ability of the serum from patients with rheumatoid arthritis to interfere with complement-fixation tests. Heimer, Levin, Primack, Corcos, and Nosenzo (1962) and Heimer, Levin, and Kahn (1963) found that a factor in rheumatoid serum will mask complement consumption by competing with complement for the binding sites on the sensitized cells. Zvaifler and Bloch (1962) found that inhibition of complementfixation was proportional to the RF titre. Further, Davis and Bollet (1964) found that RF could protect an enzyme-anti-enzyme system from the inhibitory effects of serum complement; RF blocked complement-fixation, resulting in recovery of complement in the supernatant fluid in active form. Volkert (1959) noted that the outcome of complementfixation tests might be determined by a balance between non-specific inhibitors and anti-inhibitors present in the antigen preparations as well as in the sera.

The results observed in this study on pregnant women with RF may be explained by the "complement sparing" effect of RF, since the ability to produce complement-fixing antibody in high titre was not significantly different in the test and control groups. It would be of interest to remove RF from the sera of sero-positive subjects and to see if their ability to produce complement-fixing antibodies is truly diminished as compared with that of subjects lacking RF. However, Heimer, Levin, Primack, Corcos, and Nosenzo (1962) found that human sera contain a number of inhibitors of complementfixation and thus a large number of carefully-controlled tests would be needed to clarify this point, as many of the procedures for isolation of RF are in themselves anticomplementary. Nevertheless, the antibody potential of individuals with RF as determined by complement-fixation tests must await a more thorough study of these mechanisms of inhibition.

Thus, some of the discrepancies in the literature regarding the antibody responses of individuals with RF may result from interactions of RF with the antibody-antigen system. 


\section{Summary}

Complement-fixing anti-viral antibodies in a group of normal pregnant women whose sera gave positive tests for rheumatoid factor showed a lower incidence of antibodies than did their matched controls. The differences were accentuated when a selected group of these women with high rheumatoid factor titres were compared with their controls. However, the known "complement-sparing" effect of rheumatoid factor makes it uncertain whether these differences are ascribable to differences in the antibody potential of these individuals.

In no instance could any of the 27 virus antigens, as measured by these anti-viral antibodies, be implicated as the agent probably eliciting the rheumatoid factor in these patients.

\section{REFERENCES}

Bach, G. L., Grieble, H. G., and Anderson, T. O. (1965). Clin. Res., 13, 284.

Davis, J. S., and Bollet, A. J. (1964). J. Immunol., 92, 139.

Dixon, W. J., and Massey, F. J., Jr. (1951). In "Introduction to Statistical Analysis", pp. 247-254. McGraw-Hill, New York.

Dresner, E., and Trombly, P. (1959). New Engl. J. Med., 261, 981.

Heimer, R., Levin, F. M., and Kahn, M. F. (1963). J. Immunol., 91, 866.

__, _- Primack, A., Corcos, J. M., and Nosenzo, C. (1962). Ibid., 89, 382.

Johnson, R. E., and Hall, A. P. (1958). New Engl. J. Med., 258, 743.

Meiselas, L. E., Zingale, S. B., Lee, S. L., Richman, S., and Siegel, M. (1961). J. clin. Invest., 40, 1872.

Rawson, A. J., Abelson, N. M., and McCarty, D. J. (1961). Arthr. and Rheum., 4, 463.

Sever, J. L. (1962). J. Immunol., 88, 320.

, Heubner, R. J., Castellano, G. A., and Bell, J. A. (1963). Amer. Rev. resp. Dis., 88, 342.
Svec, K. H., and Dingle, J. H. (1965). Arthr. and Rheum., $8,524$.

Volkert, M. (1959). Acta path. microbiol. scand., 47, 393.

Waller, M. V., Decker, B., Toone, E. C., and Irby, R. (1961). Arthr. and Rheum., 4, 579.

Zvaifler, N. J., and Bloch, K. J. (1962). Ibid., 5, 127.

\section{Le rapport entre les anticorps anti-viraux et le facteur rhumatoide chez les femmes enceintes}

\section{RÉSUMÉ}

L'incidence des anticorps anti-viraux fixant le complément chez des femmes enceintes normales séro-positives pour le facteur rhumatoïde fut moindre que chez les témoins assorties. Cette différence fut accentuée lorsqu'on choisit parmi ces femmes un groupe avec un titre élevé du facteur rhumatoïde et on le compara avec un groupe $\dot{\omega}$ témoin. Toutefois, l'effet bien connu d' "épargne du 걱 complément" du facteur rhumatoïde rend douteuse l'hypothèse que ces différences soient attribuables à des différences dans le potentiel de l'anticorps chez ces sujets.

On ne put impliquer aucun des 27 antigènes anti-viraux, mesurés par ces anticorps anti-viraux, comme agent tirant au clair le facteur rhumatoïde chez ces sujets.

\section{La relación entre los anticuerpos anti-virales y el factor reumatoide en mujeres embarazadas}

\section{Sumario}

$\mathrm{La}$ incidencia de los anticuerpos anti-virales fijando el complemento en mujeres embarazadas normales seropositivas para el factor reumatoide fué menor que en $\odot$ testigos emparejadas. Esta diferencia fué acentuada al $\overrightarrow{\vec{D}}$ elegir entre estas mujeres un grupo con cifras altas de 윽 factor reumatoide y al compararle con un grupo testigo. Sin embargo, el efecto conocido de "ahorro de complemento" del factor reumatoide pone en duda la hipótesis de que estas diferencias se puedan atribuir a diferencias en el potencial del anticuerpo en estos sujetos.

En ningún caso se pudo implicar uno de los 27 antígenos anti-virales, medidos por estos anticuerpos anti-virales, como agente descubridor del factor reumatoide en estos sujetos. 